3. Історія української культури/ під заг. ред. І. Крипякевича. - Львів : Вид-во Івана Тиктова, 1937. - $1036 \mathrm{c.}$

4. Каган М. С. Человеческая деятельность (Опыт системного анализа) / М.С. Каган. М. : Политиздат, 1974. - 328 с.

5. Канцедикас А. Искусство и ремесло. К вопросу о природе народного искусства / А. Канцедикас. - М. : Изобр. искусство, 1977. - 120 с.

6. Концепція технологічної освіти учнів загальноосвітніх навчальних закладів України [Електронний ресурс]. - Режим доступу : // http://www.rer.ptosvita.org. - Загол. з екрану

7. Палаткина Г.В. Мультикультурное образование: современный поход к воспитанию на народных традициях / Г.В. Палаткина // Педагогика. - 2002. - №5.

Стаття надійшла до редакції 17.04.2012 р.

УДК 373.5.016:53

Н. В.Форкун, аспірант,

Кам'янещь-Подільський національний університет імені Івана Огієнка

\title{
КОМПЕТЕНТНІСНИЙ ПІДХІД ДО ВИКЛАДАННЯ ФІЗИКИ У СТАРШІЙ ШКОЛІ
}

Форкун Н. В. Компетентнісний підхід до викладання фізики у старшій школі.

У статті розглянуто шляхи реалізації компетентнісного підходу до викладання фізики у старшій школі.

Ключові слова: компетентнісний підхід, старша школа, фізика, інтелект-карта.

Форкун Н. В. Компетентносный подход к преподаванию физики в старшей школе.

В статье рассмотрены пути реализации компетентностного подхода к преподаванию физики в старшей школе.

Ключевые слова: компетентностный подход, старшая школа, физика, интеллект-карта.

Forkun N. Competence approach to teaching physics in high school.

In the article reviews ways to implement the competence approach in the process of study of physics of senior school pupils.

Key words: competence approach, physics, senior school, mind map.

Постановка проблеми. Суспільство вимагає виховання самостійних, ініціативних і відповідальних громадян, здатних ефективно взаємодіяти у розв'язанні соціальних, виробничих та економічних завдань. У світлі приєднання України до Болонського процесу змін потребує не лише процес навчання у вищій школі, але й навчання у старшій школі, яке є невід'ємною й важливою сходинкою до вищої освіти. Компетентнісний підхід у шкільній освіті є вимогою часу.

Аналіз актуальних досліджень. Проблемами компетентнісного підходу до навчання цікавляться багато науковців: як вітчизняних, так і зарубіжних. Дослідженням теорії, методики, умов впровадження компетентнісного підходу до навчального процесу займаються П. Атаманчук, С. Величко, О. Іваницький, А. Заболотний, О. Пометун, О. Савченко, О. Овчарук, А. Хуторський та інші. Однак, незважаючи на суттєві наукові, теоретичні розробки, проблема практичної реалізації компетентнісного підходу до навчання фізики у старшій школі залишається відкритою. 
Виклад основного матеріалу. Насамперед, 3'ясуємо суть вихідних понять. Н. Бібік аналізує компетентнісний підхід в освіті як переорієнтацію «3 процесу на результат освіти в діяльнісному вимірі» [2]. Компетентнісний підхід акцентує увагу на результатах освіти, причому як результат освіти розглядається не сума засвоєної інформації, а здатність людини діяти у різних проблемних ситуаціях [5].

Компетентнісний підхід передбачає зміщення акценту з накопичування нормативно визначених знань, умінь і навичок до формування й розвитку в учнів здатності практично діяти, застосовувати індивідуальні технології і набутий досвід успішної діяльності у виконанні необхідних функцій професійної та соціальної практики. Іншими словами, перспективність компетентнісного підходу полягає в тому, що він передбачає високу готовність випускника школи до успішної діяльності в різних сферах соціальної практики [3, с.71-72].

Компетентнісний підхід - спрямованість навчально-виховного процесу на досягнення результатів, якими $\epsilon$ такі ієрархічно-підпорядковані компетентності учнів, як ключова, загальнопредметна і предметна. Навчальні досягнення, яких молодь нині набуває в процесі навчання в школі, безперечно, $є$ дуже важливими. Однак, поряд із цим, актуальними $є$ поняття компетентності учня, набуття ним набору компетентностей, що, на думку багатьох зарубіжних експертів, визначається багатьма чинниками [6].

Під ключовими компетентностями особистості, як правило, розуміють відносно універсальні, застосовані в широкому спектрі життєвих ситуацій компетентності [2, с.16-25].

Реалізація компетентнісного підходу в навчанні фізики, на нашу думку, полягає у розв'язанні таких основних завдань: визначення структури діяльності з позицій компетентнісного підходу, диференціація предметного змісту, розроблення, вибір і використання на практиці методів, прийомів, засобів, інноваційних технологій навчання, створення простої і об'єктивної системи моніторингу.

Нова методологія навчання - це безперервний процес, в якому індивід має змогу виявити власне «Я» через висловлення особистого розуміння нового для нього явища, процесу, виявляючи свій стиль мислення, через самостійне поповнення знань, пошук власного ефективного способу навчально-пізнавальної діяльності і пізнання світу, самооцінювання i самовизначення за наявності критеріїв оцінювання і банку вибору, відкриття своїх власних нахилів, здібностей, талантів [1, с.145]. Окрім того, варто підкреслити, що школа в основному зорієнтована на розвиток наукового мислення учня, приділяючи недостатньо уваги розвитку емоційно-образного, художнього мислення, хоча загальновідома істина про функціональну асиметрію мозку людини: ліва півкуля відповідає за логічне мислення, права - за образне. Дуже мало людей на Землі збалансовано використовують обидві півкулі мозку. У більшості переважно «працює» ліва півкуля і майже не використовується потенціал правої. Практикою доведено, що учням 
важко дається навчання, засноване лише на логічному мисленні й механічному запам'ятовуванні. Багато майбутніх геніїв людства вважалися тугодумами, не здібними до навчання (наприклад, Ейнштейн, Едісон, Фарадей тощо). Поділяємо позицію науковця Б. Неменського, який зазначав, що обмеженість одностороннього наукового навчання рано чи пізно має бути подоланою. Ми витрачаємо на цій односторонності величезні можливості творчого мислення, оскільки для цього потрібен багатий світ асоціацій, розвинуті емоційно-ціннісні критерії у кожної людини, якою б не була iii професія. Позанаукове, художнє пізнання існує і йому має бути свідомо і цілеспрямовано відкрита дорога в школу» [4].

У практиці роботи ми використовуємо технологію створення інтелект карт (з англ. mindmap - карти пам'яті, інтелект-карти). Вони сприяють гармонійному розвиту обох півкуль мозку. Інтелект-карта $\epsilon$ зручною й ефективною технікою альтернативного запису, яка допомагає відновити в пам’яті матеріал, узагальнити його, глибше пізнати, усвідомити, зв’язати із життям. Інтелект карта становить плід уяви учня на базі асоціацій, які в нього викликала почута, прочитана інформація про явище, процес, закон тощо. Створенням карт учні можуть займатися як індивідуально, так і в групах.

Основні вимоги до інтелект карт та її матеріалів:

- відповідність темі;

- логічність, аргументованість, цікавість, важливість, сучасність інформаціі;

- відповідність віковим можливостям для сприйняття; робота має бути оформлена відповідно до вимог українського правопису;

- якість ілюстрацій і відповідність теоретичному матеріалу;

- дотримання вимог технології створення інтелект карт;

- загальний внесок учня у роботу групи (якщо інтелект карта створювалася групою учнів);

- спроможність зробити узагальнення теми з використанням частини інтелект карти будь-якої групи.

Наведемо приклад використання карт розуму в навчанні фізики (старша школа) на основі компетентнісного підходу. Під час вивчення теми «Резонанс» (10 клас, розділ «Механічні коливання і хвилі»), учні створили інтелект карту (див. рис.1).

Проаналізуємо їі, скориставшись схемою вивчення й опису фізичного явища:

1. Показати явище, з’ясувати умови його виникнення й існування, в чому воно полягає. Підкреслити об’єктивний характер явища, незалежність його від наших знань і уявлень. Звернути увагу на необхідність його аналізу. До якого типу взаємодій можна віднести дане явище? Які тіла чи системи взаємодіють?

2. Опишіть дане явище якісно.

3. Обрати систему відліку, в якій аналізуватиметься явище. Для цього треба знати, яку форму має явище в різних системах відліку. Визначити, в якій з них зв’язок між величинами $є$ найпростішим, найдоступнішим для дослідження і опису. 


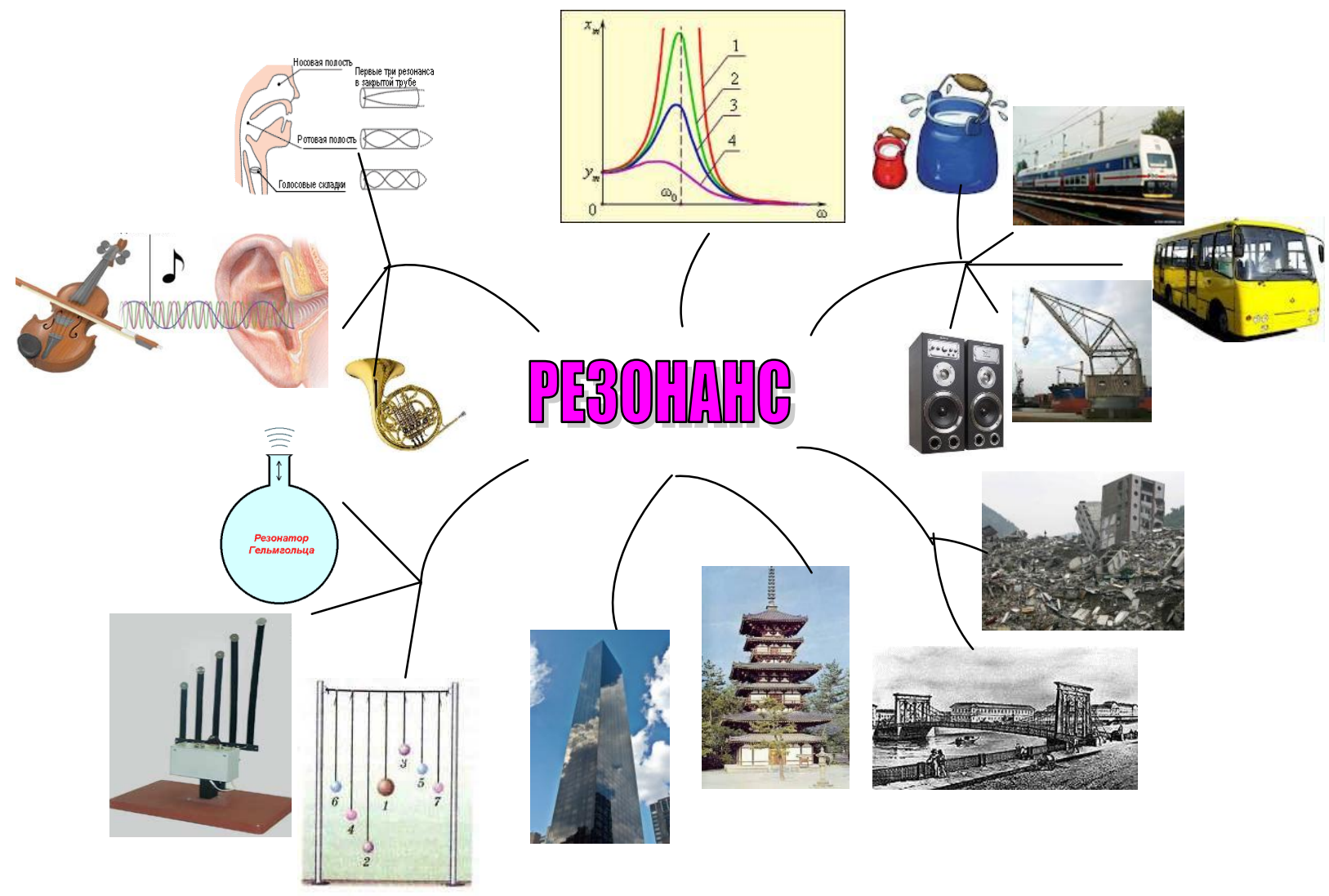

Рис.1 Інтелект-карта «Резонанс»

4. Увести кількісні характеристики сторін явища, простежити за їхніми змінами у просторі і часі, установити їхні взаємозв'язки - окремі закони. Які моделі використовуються під час пояснення явища?

5. Проаналізувати закони. Спробувати зобразити закономірності за допомогою числових послідовностей, графіків, діаграм, супроводжуючи словесними описами і формулюваннями.

6. Установити взаємний зв'язок законів, що описують явище, дістати нові зв'язки теоретичним і експериментальним шляхом.

7. Показати зображення явища у різних системах відліку, тобто порівняти характеристики, числові значення, характер змін, закономірності. Виявити, що залишається однаковим, що змінюється і яким чином. Зробити відповідні висновки.

8. Розкрити суть явища, використовуючи різні способи зображення, i спробувати узагальнити окремі закономірності у можливо більш загальній формі, тобто у теорію явища. На основі цієї теорії дати пояснення окремим фактам.

9. Перевірити відповідність теорії і дослідних даних.

10. Подати наукове значення теорії явища, вказавши на іiі сильні i слабкі сторони, область застосування моделі явища. Показати цінність ऑï, використавши на практиці [1, с.197-198].

Варто зауважити, що користуючись картою, учні зможуть у будь-який час (після вивчення теми, розділу, курсу) відновити в пам'яті матеріал i 
пояснити фізичну суть явища резонансу, провести демонстрацію, розкрити наукове значення, користь і шкоду явища, можуть дати рекомендації щодо способів практичного уникання шкідливої дії резонансу.

Окрім того, для кращого забезпечення навчально-пізнавального процесу учням пропонуємо еталонні завдання засобом завуальованих формулювань учителя [1]:

- завчені знання - «Розкажіть про...», «Як називається...»;

- розуміння головного - «Сформулюйте іншими словами», «Виділіть головне 3 прочитаного», «Відтворити головний зміст в структурі»;

- наслідування - «Навести аналогічний до попереднього приклад»;

- грунтовне i вичерпне володіння знаннями - «Розкласти на складові частини», «Висловити критичні зауваження», «Пояснити, як і чому...»;

- уміння застосовувати знання - «Пояснити мету застосування», «Висловити критичні зауваження», «Підсумувати»;

- навичка - «Використовуючи схему, алгоритм, розказати...», «Подібно до.., виконати...»;

- переконання - «Як же бути, коли...», «3 позиції...», «Висловити свої ідеї щодо...», «Як, на вашу думку, можна застосувати явище в побуті?»

Практика доводить, що використання інноваційних технологій навчальної діяльності старшокласників формує науковий світогляд учнів, розкриває роль фізичного знання і житті людини і суспільному розвитку, розвиває креативність, творчість, оригінальність, образне мислення, формують компетенції старшокласника, прогнозує подальшу діяльність майбутнього випускника.

Висновки. Розроблення методики впровадження компетентнісного підходу у старшій школі сприятиме поліпшенню якості освіти. Саме від школи залежить, якою мірою у випускників будуть сформовані ключові компетентності. Адже державі необхідні компетентні особистості, які адаптовані до соціального середовища, здатні змінюватися, які вміють аналізувати, критично мислити, розв’язувати нестандартні завдання, будуть успішними.

Обгрунтування змісту та дослідження механізмів формування компетентностей старшокласників $є$ перспективними напрямами наших подальших досліджень.

\section{Література}

1. Атаманчук П.С. Дидактичне забезпечення семінарських занять 3 курсу «Методика навчання фізики» (загальні питання): навчально-методичний посібник/ П.С. Атаманчук, О.М. Семерня, Т.П. Поведа. - Кам'янець-Подільський: Кам'янецьПодільський національний університет імені івана Огієнка, 2010. - 392 с.

2. Бібік Н.М. Компетентнісний підхід: рефлексивний аналіз застосування/ Н.М. Бібік// Компетентнісний підхід у сучасній освіті: світовий досвід та українські перспективи. - К.: «К.І.С.», 2004. - С.45-50.

3. Компетентнісний підхід в сучасній освіті: світовий досвід та українські перспективи: Бібліотека з освітньої політики/ за заг. ред О.В.Овчарук. - К.: «К.І.С.», 2004. - 112 с.

4. Неменский Б.М. Вненаучные формы познания/ Б.М.Неменский// Советская педагогика. - 1991. - №9. - С.40-45. 
5. Паращенко Л.І. Технологія формування ключових компетентностей у старшокласників: практичні підходи / Л.І.Паращенко // Компетентнісний підхід у сучасній освіті: світовий досвід та українські перспективи: Бібліотека 3 освітньої політики/ за заг. ред. О.В. Овчарук. - К.: «К.І.С.», 2004. - С.71-84.

6. Пометун О.М. Компетентнісний підхід - найважливіший орієнтир розвитку сучасної освіти/ О.М.Пометун// Рідна школа. - 2005. -№9. - С.60-65.

7. Хуторской А.В. Ключевые компетенции: технология конструирования/ А.В. Хуторской// Народное образование. - 2003. - №5. - С.55-61.

Стаття надійшла до редакції 28.05.2012 р.

УДК 378.147

В. Т. Легун, директор ДПТНЗ №7, «Навчально-виробничий иеентр», м. Кривий Ріг

\section{КОМПЕТЕНТНІСНИЙ ПІДХІД У ПРОЦЕСІ ПРОФЕСІЙНОГО СТАНОВЛЕННЯ ОСОБИСТОСТІ МАЙБУТНЬОГО ФАХІВЦЯ}

Легун В. Т. Компетентнісний підхід у проиесі професійного становлення особистості майбутнього фахівия.

У статті розглянуто особливості компетентнісного підходу в процесі навчання, щзо впливають на формування сойіально значущих якостей особистості майбутнього фахівия $i$ надають можливість забезпечити на достатньому рівні його професійне становлення.

Ключові слова:компетентнісний підхід, соціально значущі якості особистості, професійне становлення.

Легун В.Т. Компетентностный подход в процессе профессионального становления личности будущего спещиалиста.

В статье рассмотрены особенности компетентностного подхода в процессе обучения, которые влияют на формирование сочиально значимых качеств личности будущего специалиста и дают возможность обеспечить на достаточном уровне его профессиональное становление.

Ключевые слова: компетентностный подход, сочиально значимые качества личности, профессиональное становление.

Lehun $V$. Competence approach during professional formation of future expert.

The article discusses the features of the competency approach to learning that affect the formation of socially significant qualities of future professional and make it possible to provide a sufficient level of his professional development.

Key words: competence approach, socially significant personality traits, professional development.

Процеси глобалізаційних трансформацій, перебудови політичної, економічної, соціокультурної сфер діяльності суспільства, впровадження ринкової економіки, гостро потребують формування нової генерації фахівців. Конкурентноспроможність $є$ одним з основних показників якісного стану соціально-трудової діяльності. У зв'язку з цим актуальним є розглядання питання інноваційних технологій, які дадуть можливість забезпечити на достатньому рівні професійне становлення особистості майбутнього фахівця.

Розв'язання цієї проблеми вбачається тільки через докорінне реформування освіти в українській державі і виведення іï на рівень розвинених країн світу. Головною передумовою високого рівня розвитку особистості й невпинної інтелектуалізації нації $\epsilon$ перехід найбільш розвинених держав від індустріального виробництва до науково- 